Article

\title{
First Detection of Human ST131-CTX-M-15-O25-B2 Clone and High-Risk Clonal Lineages of ESBL/pAmpC-Producing E. coli Isolates from Diarrheic Poultry in Tunisia
}

\author{
Ahlem Jouini ${ }^{1, *}$, Amira Klibi ${ }^{1}$, Imen Elarbi ${ }^{1}$, Meriem Ben Chaabene ${ }^{1}$, Safa Hamrouni ${ }^{1}$, Oussema Souiai ${ }^{2}$, \\ Mariem Hanachi ${ }^{2,3}$, Abdeljelil Ghram ${ }^{1}$ and Abderrazak Maaroufi ${ }^{1}$ \\ 1 Laboratory of Epidemiology and Veterinary Microbiology, Group of Bacteriology and Biotechnology \\ Development, Institut Pasteur de Tunis, University of Tunis El Manar, Tunis 2092, Tunisia; \\ klibi.amira@yahoo.fr (A.K.); Imen.Larbi@pasteur.tn (I.E.); chaabene.meriem@gmail.com (M.B.C.); \\ safa.hamrouni@pasteur.tn (S.H.); Abdeljelil.Ghram@pasteur.tn (A.G.); \\ Abderrazak.Maaroufi@pasteur.tn (A.M.) \\ 2 Laboratory of Bioinformatics, Biomathematics and Biostatistics-LR16IPT09, Institute Pasteur de Tunis, \\ University of Tunis El Manar (UTM), Tunis 2092, Tunisia; oussema.souiai@pasteur.tn (O.S.); \\ mariem.hanachi@gmail.com (M.H.) \\ 3 Faculty of Sciences of Bizerte, University of Carthage, Jarzouna-Bizerte 7021, Tunisia \\ * Correspondence: ahlem.jouini@pasteur.tn; Tel.: +216-71-783-022
}

Citation: Jouini, A.; Klibi, A.; Elarbi, I.; Chaabene, M.B.; Hamrouni, S.; Souiai, O.; Hanachi, M.; Ghram, A.; Maaroufi, A. First Detection of Human ST131-CTX-M-15-O25-B2 Clone and High-Risk Clonal Lineages of ESBL/pAmpC-Producing E. coli Isolates from Diarrheic Poultry in Tunisia. Antibiotics 2021, 10, 670. https://doi.org/10.3390/ antibiotics10060670

Academic Editor: Laura J. Rojas

Received: 2 March 2021

Accepted: 29 April 2021

Published: 4 June 2021

Publisher's Note: MDPI stays neutral with regard to jurisdictional claims in published maps and institutional affiliations.

Copyright: (c) 2021 by the authors. Licensee MDPI, Basel, Switzerland. This article is an open access article distributed under the terms and conditions of the Creative Commons Attribution (CC BY) license (https:// creativecommons.org/licenses/by/ $4.0 /)$.

\begin{abstract}
Circulation of a multi-resistance clone of bacteria associated with genetic elements in diseased animals constitutes a global public health problem. Our study focused on the characterization of the support of ESBL in cefotaxime resistant E. coli $\left(\mathrm{CTX}^{\mathrm{R}}\right)$ isolates recovered from poultry with diarrhea, analysis of their clonal lineage, and virulence-associated genes. The study was carried out on 130 samples of chickens with diarrhea, collected in 2015 from poultry farms in Tunisia. Isolates of $20 \mathrm{CTX}^{\mathrm{R}}$ E. coli strains were identified as ESBL and AmpC $\beta$ - lactamase producers. The following $\beta$-lactamase genes (number of isolates) were detected: $b l a_{\mathrm{CTX}-\mathrm{M}-15}+b l a_{\mathrm{OXA} 1}(4), b l a_{\mathrm{CTX}-\mathrm{M}-15}+b l a_{\mathrm{OXA} 1}$ $+b l a_{\mathrm{TEM}-1 \mathrm{~b}}(2), b l a_{\mathrm{CTX}-\mathrm{M}-1}+b l a_{\mathrm{TEM}-1 \mathrm{~b}}(9), b l a_{\mathrm{CTX}-\mathrm{M}-1}(2), b l a_{\mathrm{CMY} 2}+b l a_{\mathrm{TEM}-1 \mathrm{~b}}$ (3). Six E. coli harboring $b l a_{\mathrm{CTXM}-15}$ were allocated to ST131-B2-O25b-; six and three bla $a_{\mathrm{CTX}-\mathrm{M}-1}$ were grouped in ST155, ST10, and ST58, respectively, related to the phylogroup D and A. The $q n r B$ gene, the variant $a a c\left(6^{\prime}\right)-I b-c r$, and the class 1 integrons with different gene cassettes, were detected amongst our 20 isolated strains, which were classified as ExPEC and aEPEC. Our findings highlighted the emergence of the human pandemic ST131-CTX-M-15-O25-B2 clone and the high risk of such clonal lineage strains in diarrheic poultry, in Tunisia, which could constitute a risk of their transfer to healthy animals and humans.
\end{abstract}

Keywords: ESBL; ST131; clonal lineages; pAmpC; diarrheic poultry; pathogenic bacteria

\section{Introduction}

Escherichia coli is a common microorganism of the intestinal microbiota of humans and animals and may be involved as an opportunistic and zoonotic pathogen for humans and animals [1]. Pathogenic E. coli in food-producing animals can cause serious economic losses in livestock related to bovine mastitis, avian colibacillosis, and diarrhea. Diarrhea is considered a major health concern in poultry and contributes significantly to economic losses in the poultry industry in Tunisia and worldwide since it leads to mortality, seizures, and reduction of performances in slaughterhouses [2]. Bacterial diarrhea or dysbacteriosis, a non-specific bacterial enteritis, is another highly cited cause of wet excreta. Dysbacteriosis is due to the imbalance of the intestinal microbiota caused by several non-infectious and infectious factors such as coccidia and Clostridium perfringens. Dysbacteriosis may also be a result of an abrupt change in feed or other stress factors, which upset the usual microbial balance in the intestine. Pathogenic bacteria, like Escherichia coli, Campylobacter jejuni, and Spirochaetes, as well as several viruses, are known to be involved as causative agents of avian 
diarrhea. Indeed, E. coli often infects poultry via the gastrointestinal tract and causes diarrhea and septicemia. Pathogenic strains have been divided into extraintestinal pathogenic E. coli (ExPEC) and intestinal pathogenic E. coli (diarrheagenic; DEC). Enteropathogenic E. coli (EPEC) is one of the six pathotypes of diarrheagenic E. coli that produce severe infant diarrhea [3]. EPEC can produce attaching and effacing lesions, which are characterized by intimate bacterial attachment coding eae gene and classified as typical EPEC (tEPEC) and atypical (aEPEC). This classification depends on the presence or absence of the bundle forming pilus A $(b f p A)$ gene. The reservoir for (tEPEC) is considered in humans; in contrast, (aEPEC) strains are more prevalent in animals [4].

Over the last few years, there was a worrisome global health problem concerning extended spectrum-beta-lactamase (ESBL)-producing E. coli in human and animal infections, in both hospital and livestock settings [1]. ESBL-producing E. coli isolates, especially those producing ESBL of CTX-M type, have increasingly been reported worldwide over the last two decades [1,2]. Based on the diversity of ESBL enzymes among E. coli isolates from African livestock, those belonging to the CTX-M-1 group have been reported to be more frequent than the classical SHV- and TEM- ESBL enzymes [2,5]. CTX-M-1 and CTX-M-14 enzymes are so far the most common ESBLs in E. coli isolated from livestock, especially poultry and food products of animal origin [5,6]. Nevertheless, the CTX-M-15 enzyme is the most common enzyme largely disseminated in the clinical settings, as well as in the community with few exceptions, worldwide [7]. The successful spread of the CTX-M-15 enzyme is largely attributed to its association with the highly virulent pandemic lineage ST131-O25b-B2 E. coli. This clonal lineage is a major cause of severe human extraintestinal infections, including community-acquired urinary tract infections [8]. In addition, it has also been reported in companions and non-companion animals with human contact, in some countries [9]. Indeed, a large multinational European report showed that $6 \%$ of ESBLproducing E. coli, isolated from various companion animals, belonging to E. coli ST131 [9]. This clonal lineage has also been reported at low frequencies in livestock, food products of animal origin, vegetables, as well the environment [9].

The scarce occurrence of E. coli ST131 favors the hypothesis that humans, rather than the companion and food-producing animals, serve as the primary reservoir of such clone [9].

There are a few reports of clinical infections of animals caused by E. coli ST131, especially in poultry livestock. Therefore, surveillance of foodborne pathogens, drug resistance, and virulence determinants are important for conducting epidemiological analysis of such factors, designing risk management, and strategic control of poultry farming; these data being highly relevant to public health.

This study aimed to characterize the support of ESBL in cefotaxime resistant $E$. coli $\left(C T X^{R}\right)$ isolates recovered from poultry with diarrhea and analyze their clonal lineages, as well as the presence of virulence-associated genes to find out the potential threat to food safety and risk to public health of circulating pandemic multi-resistance clone in chickens.

\section{Results}

\subsection{E. coli Recovery from Poultry Samples}

Cefotaxime-resistant isolates (CTXR) were recovered in 20 out of $130(15.5 \%)$ analyzed samples, with 11/80 (13.75\%) from feces and 9/50 (18\%) from tracheal swabs. Details of pathogen isolation are presented in Table 1 and Figure S1 (Supplementary material). Only positive fecal and tracheal samples are presented. Biochemical and molecular identification showed that the 20 isolates were assigned to $E$. coli species harboring the specific gene $i u d A$. Fourteen recovered $E$. coli isolates from fecal and tracheal animal samples, collected from a different department, were labeled as (strain/chicken $\mathrm{n}^{\circ}$ ): EC1, EC2/C1; EC3, EC4/C5; EC5, EC7/C9; EC9, EC15/EC6; EC10, EC11/C4; EC13, EC14/C8; EC18, EC19/EC10. 
Table 1. Phenotypic and genotypic characteristics of 20 positive cefotaxime-resistant $E$. coli, recovered from fecal and tracheal samples of a diarrheic chicken farm in Tunisia.

\begin{tabular}{|c|c|c|c|c|c|c|c|c|}
\hline Strains & Department & Chicken $\mathbf{N}^{\circ}$ & Swabs & $\begin{array}{l}\text { Profiles of Resistance to } \\
\text { Non- } \beta \text {-Lactams }\end{array}$ & $\begin{array}{l}\text { Genes Encoding } \\
\text { Beta-Lactamases }\end{array}$ & $\begin{array}{c}\text { bla }_{\text {CTX-M Genetic }} \\
\text { Environment }\end{array}$ & $\begin{array}{l}\text { Gene Cassette Arrays in } \\
\text { Class } 1 \text { Integrons }\end{array}$ & $\begin{array}{l}\text { Other Resistance Genes } \\
\text { Detected outside Integrons }\end{array}$ \\
\hline EC1 & 1 & $\mathrm{C} 1$ & $\mathrm{~T}$ & NAL, SUL, SXT, TET, S & $b l a_{\mathrm{CTX}-\mathrm{M}-15}+b l a_{\mathrm{OXA}-1}$ & ISEcp1/IS26-orf477 & dfrA17-aadA5 & tet $A$, sul2, sul3, aac $\left(6^{\prime}\right)-\mathrm{Ib}-\mathrm{cr}$ \\
\hline EC2 & 1 & $\mathrm{C} 1$ & $\mathrm{~F}$ & NAL, SUL, TET & $b l a_{\mathrm{CTX}-\mathrm{M}-15}+b l a_{\mathrm{OXA}-1}$ & ISEcp1/IS26-orf477 & ND & $\operatorname{tet} A, \operatorname{aac}\left(6^{\prime}\right)-\mathrm{Ib}-c r$, sul2 \\
\hline EC3 & 5 & C5 & $\mathrm{F}$ & NAL, SUL, SXT, TET, S & $b l a_{\mathrm{CTX}-\mathrm{M}-15}+b l a_{\mathrm{OXA}-1}$ & ISEcp1/IS26-orf477 & $d f r A 17-a a d A 5$ & $\operatorname{tet} A$, aac $\left(6^{\prime}\right)-\mathrm{Ib}-c r$, sul2 \\
\hline EC5 & 9 & C9 & $\mathrm{T}$ & NAL, CIP, TET, S & $b l a_{\mathrm{CTX}-\mathrm{M}-1}+b l a_{\mathrm{TEM}-1 \mathrm{~b}}$ & ISEcp1-orf477 & ND & tetB, aad $A 1$, qnrB \\
\hline EC6 & 3 & $\mathrm{C} 3$ & $\mathrm{~T}$ & NAL, CIP, SUL, SXT, S & $b l a_{\mathrm{CTX}-\mathrm{M}-1}+b l a_{\mathrm{TEM}-1 \mathrm{~b}}$ & ISEcp1-orf477 & $d f r A 1-a a d A 1$ & tetB, qnrB, sul2, sul3 \\
\hline EC7 & 9 & C9 & $\mathrm{F}$ & SUL, TET & $b l a_{\mathrm{CTX}-\mathrm{M}-1}+b l a_{\mathrm{TEM}-1 \mathrm{~b}}$ & Unknown-orf 477 & ND & tet $A$, sul2 \\
\hline EC8 & 12 & $\mathrm{C} 12$ & $\mathrm{~F}$ & NAL, CIP, SUL, SXT, TET, S & $b l a_{\mathrm{CTX}-\mathrm{M}-1}+b l a_{\mathrm{TEM}-1 \mathrm{~b}}$ & Unknown-orf477 & dfrA1-aadA1 & tet $A$, qnr $B$, sul 3 \\
\hline EC9 & 6 & $\mathrm{C} 6$ & $\mathrm{~T}$ & NAL, SUL, SXT, TET, S, C & $b l a_{\mathrm{CTX}-\mathrm{M}-1}+b l a_{\mathrm{TEM}-1 \mathrm{~b}}$ & ISEcp1-orf477 & $d f r A 1-a a d A 1$ & tet $A$, qnrB, sul2 \\
\hline EC11 & 4 & $\mathrm{C} 4$ & $\mathrm{~T}$ & SUL, TET & $b l a_{\mathrm{CTX}-\mathrm{M}-1}+b l a_{\mathrm{TEM}-1 \mathrm{~b}}$ & ISEcp1-orf477 & ND & tetB, sul2 \\
\hline EC12 & 7 & C7 & $\mathrm{F}$ & TET, C & $b l a_{\mathrm{CTX}-\mathrm{M}-1}+b l a_{\mathrm{TEM}-1 \mathrm{~b}}$ & ISEcp1-orf477 & ND & tetB \\
\hline EC13 & 8 & $\mathrm{C} 8$ & $\mathrm{~F}$ & SUL, SXT, TET, S & $b l a_{\mathrm{CTX}-\mathrm{M}-15}+b l a_{\mathrm{OXA}-1}+b l a_{\mathrm{TEM}-1 \mathrm{~b}}$ & ISEcp1-orf 477 & dfrA17-aadA5 & tet $A$, sul2 \\
\hline EC 14 & 8 & $\mathrm{C} 8$ & $\mathrm{~T}$ & NAL, CIP, SUL, SXT, S & $b l a_{\mathrm{CTX}-\mathrm{M}-15}+b l a_{\mathrm{OX}} 1, b l a_{\mathrm{TEM}-1 \mathrm{~b}}$ & ISEcp1-orf 477 & $d f r A 17-a a d A 5$ & $\operatorname{aac}\left(6^{\prime}\right)-\mathrm{Ib}-c r$, sul2 \\
\hline EC15 & 6 & C6 & $\mathrm{F}$ & NAL, CIP, S & $b l a_{\mathrm{CTX}-\mathrm{M}-1}+b l a_{\mathrm{TEM}-1 \mathrm{~b}}$ & ISEcp1-orf477 & dfrA12-aadA2 & $a a c\left(6^{\prime}\right)-\mathrm{Ib}-c r$ \\
\hline EC16 & 13 & $\mathrm{C} 13$ & $\mathrm{~F}$ & SUL, SXT, S & $b l a_{\mathrm{CTX}-\mathrm{M}-1}$ & ISEcp1-orf477 & dfrA12-aadA2 & sul3 \\
\hline EC17 & 2 & $\mathrm{C} 2$ & $\mathrm{~F}$ & SUL, SXT, S & $b l a_{\text {CTX-M-1 }}$ & ISEcp1-orf477 & $d f r A 17-a a d A 5$ & \\
\hline EC18 & 10 & $\mathrm{C} 10$ & $\mathrm{~F}$ & SUL, SXT, TET, S & $b l a_{\mathrm{CMY}-2}+b l a_{\mathrm{TEM}-1 \mathrm{~b}}$ & ISEcp1-unknown & ND & tet $A$, sul2, str $A$ \\
\hline EC19 & 10 & $\mathrm{C} 10$ & $\mathrm{~T}$ & TET & $b l a_{\mathrm{CMY}-2}+b l a_{\mathrm{TEM}-1 \mathrm{~b}}$ & ISEcp1-unknown & ND & tet $A$ \\
\hline EC20 & 11 & C11 & $\mathrm{T}$ & SUL, SXT, TET & $b l a_{\mathrm{CMY}-2}+b l a_{\mathrm{TEM}-1 \mathrm{~b}}$ & ISEcp1-unknown & ND & tet $A$, sul 2 \\
\hline
\end{tabular}

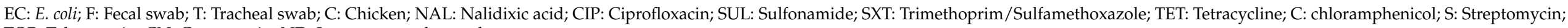
TOB: Tobramycin; CN: Gentamycin; ND: Integron non detected. 


\subsection{Antibiotic Resistance Rates}

The occurrence of antibiotic resistance in the 20 cefotaxime-resistant isolates is presented in Table 1 and Figure S1. No isolate had resistance to imipenem or ertapenem. High rates of resistance were observed for sulfonamides $(80 \%)$, tetracycline $(75 \%)$, nalidixic acid $(60 \%)$, and trimethoprim/sulfamethoxazole $(55 \%)$. However, medium and low frequency of resistance were observed for streptomycin $(30 \%)$, ciprofloxacin $(25 \%)$, chloramphenicol $(10 \%)$, tobramycin $(5 \%)$ and gentamicin $(5 \%)$. All isolates except one (E. coli 19$)$ showed multi-drug resistance phenotypes, including resistance to at least three families of antimicrobial agents. In addition, the 14 E. coli strains isolated from fecal and tracheal samples of the same animal have different antibiotic resistance patterns.

According to the Double Disc Synergy Test (DDST), 17 and three E. coli isolates were ESBL- and AmpC-producers, respectively (Table 1). Consequently, the prevalence of ESBL-positive E. coli isolates in collected samples was 13\%, and the prevalence of AmpC phenotype was $2.3 \%$.

\subsection{Characterization of $\beta$-Lactamases Gene and Genetic Environment of bla $a_{\text {Стхм Genes }}$}

The $\beta$-lactamases genes detected in the 20 cefotaxime-resistant $E$. coli isolates are summarized in Table 1 . Among the 17 ESBL-positive isolates, 11 and 6 contained bla $_{\text {CTX-M-1 }}$ either $b l a_{\mathrm{CTX}} \mathrm{M}-15$ genes, respectively; $b l a_{\mathrm{OXA}-1}$ and $b l a_{\mathrm{TEM}-1 \mathrm{~b}}$ genes being detected in 6 and 11 isolates, respectively, mainly in association with $b l_{\mathrm{CTXM}-1}$ and $b l a_{\mathrm{CTXM}-15}$ genes. The following gene associations were detected (number of isolates): $b l a_{\mathrm{CTX}-\mathrm{M}-15}+b l a_{\mathrm{OXA}-1}$ $(n=4), b l a_{\mathrm{CTXM}-15}+b l a_{\mathrm{OXA}-1}+b l a_{\mathrm{TEM}-1 \mathrm{~b}}(n=2), b l a_{\mathrm{CTXM}-1}+b l a_{\mathrm{TEM}-1 \mathrm{~b}}(n=9), b l a_{\mathrm{CTX}-\mathrm{M}-1}(2)$. The three AmpC-producing isolates harbored the $b l a_{\mathrm{CMY}-2}$, which was associated with the $b l a_{\text {TEM-1b }}$ gene in all of them.

The region surrounding the $b l a_{\mathrm{CTX}-\mathrm{M}}$ and the $b l a_{\mathrm{CMY}-2}$ detected genes are shown in Table 1 . The orf 477 sequence was present downstream of $b l a_{\mathrm{CTX}} \mathrm{M}-15$ and $b l a_{\mathrm{CTX}-\mathrm{M}-1}$ genes, in all positive isolates. In the three $b l a_{\mathrm{CMY}-2}$-positive isolates, the downstream region could not be identified despite many attempts of PCR amplification. On the other hand, the ISEcp 1 sequence was identified upstream of the $b l a_{\text {СTX-M }}$ gene, in eleven isolates and all $b l a_{\mathrm{CMY}-2}$-positive isolates. Interestingly, the IS26 flanked a partially truncated ISEcp1 element in three bla $a_{\mathrm{CTX}-\mathrm{M}-15}$ positive E. coli isolates.

\subsection{Characterization of Integrons and Resistance Mechanism to Non $\beta$-Lactam Antibiotics}

The presence of class 1 integrons was demonstrated in eleven isolates (55\%) and three gene cassette arrangements were identified in their variable regions (number of strains): $d f r A 17+\operatorname{add} A 5$ (6), dfrA1 + aadA1 (3), dfrA12 + aadA2 (2). Class 2 integrons were not detected in ours isolated strains. The $3^{\prime}$ conserved sequence (qacE $\Delta 1$-sul 1 ) was detected in all intI1-positive isolates.

A variety of resistance genes to non $\beta$-lactam antibiotics and located outside the integrons were observed in 19 out of 20 isolates (Table 1, Figure S1). The $q n r$ B and $a a c\left(6^{\prime}\right)-I b-c r$ genes were detected in four and six quinolone-resistant isolates, respectively. Tetracycline resistance was encoded by tet $(A)$ and tet (B) genes in eleven and five isolates, respectively. The sul2 and sul3 genes were detected in 13 and 4 isolates, respectively, and two strains harbored both genes.

\subsection{Phylotyping and Virulence Genotyping of E. coli}

Phylogeny analysis revealed that our isolates belong to phylogroups D (9 isolates), B2 (6 isolates), B1 (3 isolates), and A (2 isolates). Overall, the 20 ESBL/AmpC-producing E. coli isolates $(100 \%$ ) carried at least the two virulence genes (fim $A$ and $c n f 1$ ) under investigation (Table 2). However, eae, aer, papC, and pap $G$ genes were detected in six, four, ten, and six isolates, respectively. The six ST131-B2- E. coli contained five of the eight virulence genes studied and were all affiliated to the ExPEC pathovar. In addition, six ESBL-producing E. coli isolates belonging to phylogroup D were assigned to the aEPEC pathovar. The 
remaining eight isolates were attributed to the ExPEC pathovar, according to their virulencegene contents (Table 2, Figure S1).

Table 2. Clonal lineages, pathovars and virulence factor contents in 20-cefotaxime resistance E. coli recovered from diarrheic chickens farms.

\begin{tabular}{|c|c|c|c|c|}
\hline \multirow{2}{*}{ Strains } & \multirow{2}{*}{$\begin{array}{l}\text { Genes Encoding } \\
\text { Beta-Lactamases }\end{array}$} & \multirow{2}{*}{ Virulo-Type */Pathovar } & \multicolumn{2}{|c|}{ Molecular Typing } \\
\hline & & & MLST & Phylogroup \\
\hline EC1 & $b l a_{\mathrm{CTX}-\mathrm{M}-15}+b l a_{\mathrm{OXA}-1}$ & cnf1, fimA, papG,aer, papC: ExPEC & ST131 & B2 \\
\hline EC2 & $b l a_{\mathrm{CTX}-\mathrm{M}-15}+b l a_{\mathrm{OXA}-1}$ & cnf1, fimA, papG, aer, papC: ExPEC & ST131 & B2 \\
\hline EC3 & $b l a_{\mathrm{CTX}-\mathrm{M}-15}+b l a_{\mathrm{OXA}-1}$ & cnf1,fimA, papG, aer, papC: ExPEC & ST131 & B2 \\
\hline EC4 & $b l a_{\mathrm{CTX}-\mathrm{M}-15}+b l a_{\mathrm{OXA}-1}$ & cnf1,fimA, papG, aer, papC: ExPEC & ST131 & B2 \\
\hline EC5 & $b l a_{\mathrm{CTX}-\mathrm{M}-1}+b l a_{\mathrm{TEM}-1 \mathrm{~b}}$ & cnf, fimA, eae: aEPEC & ST155 & $\mathrm{D}$ \\
\hline EC6 & $b l a_{\mathrm{CTX}-\mathrm{M}-1}+b l a_{\mathrm{TEM}-1 \mathrm{~b}}$ & fimA, cnf1, eae: aEPEC & ST58 & $\mathrm{D}$ \\
\hline EC7 & $b l a_{\mathrm{CTX}-\mathrm{M}-1}+b l a_{\mathrm{TEM}-1 \mathrm{~b}}$ & fimA, cnf, aer: ExPEC & ST155 & $\mathrm{D}$ \\
\hline EC8 & $b l a_{\mathrm{CTX}-\mathrm{M}-1}+b l a_{\mathrm{TEM}-1 \mathrm{~b}}$ & fimA, cnf1, papC, eae: aEPEC & ST58 & $\mathrm{D}$ \\
\hline EC9 & $b l a_{\mathrm{CTX}-\mathrm{M}-1}+b l a_{\mathrm{TEM}-1 \mathrm{~b}}$ & fimA, cnf1, aer: ExPEC & ST155 & $\mathrm{D}$ \\
\hline EC10 & $b l a_{\mathrm{CTX}-\mathrm{M}-1}+b l a_{\mathrm{TEM}-1 \mathrm{~b}}$ & fimA, cnf1, eae: aEPEC & ST10 & $\mathrm{D}$ \\
\hline EC11 & $b l a_{\mathrm{CTX}-\mathrm{M}-1}+b l a_{\mathrm{TEM}-1 \mathrm{~b}}$ & cnf1, fimA, papC, eae: aEPEC & ST10 & $\mathrm{D}$ \\
\hline $\mathrm{EC} 12$ & $b l a_{\mathrm{CTX}-\mathrm{M}-1}+b l a_{\mathrm{TEM}-1 \mathrm{~b}}$ & cnf1, fimA, papC, eae: aEPEC & ST155 & $\mathrm{D}$ \\
\hline EC13 & $b l a_{\mathrm{CTX}-\mathrm{M}-15}+b l a_{\mathrm{OXA}-1}+b l a_{\mathrm{TEM}-1 \mathrm{~b}}$ & cnf1, fimA, papG, hly, papC: ExPEC & ST131 & B2 \\
\hline EC 14 & $b l a_{\mathrm{CTX}-\mathrm{M}-15}+b l a_{\mathrm{OXA} 1}+b l a_{\mathrm{TEM}-1 \mathrm{~b}}$ & cnf1, fimA, papG, hly, papC: ExPEC & ST131 & B2 \\
\hline EC15 & $b l a_{\mathrm{CTX}-\mathrm{M}-1}+b l a_{\mathrm{TEM}-1 \mathrm{~b}}$ & cnf1, fimA, papC, hly: ExPEC & ST155 & $\mathrm{D}$ \\
\hline EC16 & bla $a_{\mathrm{CTX}-\mathrm{M}-1}$ & cnf1, fimA: ExPEC & ST58 & A \\
\hline EC17 & $b l a_{\mathrm{CTX}-\mathrm{M}-1}$ & cnf1, fimA: ExPEC & ST10 & A \\
\hline EC18 & $b l a_{\mathrm{CMY}-2}+b l a_{\mathrm{TEM}-1 \mathrm{~b}}$ & cnf1, fimA: ExPEC & ST2179 & B1 \\
\hline EC19 & $b l a_{\mathrm{CMY}-2}+b l a_{\mathrm{TEM}-1 \mathrm{~b}}$ & cnf1, fimA: ExPEC & ST2179 & B1 \\
\hline EC20 & $b l a_{\mathrm{CMY}-2}+b l a_{\mathrm{TEM}-1 \mathrm{~b}}$ & cnf1, fimA: ExPEC & ST1011 & B1 \\
\hline
\end{tabular}

ST: sequence type; cnf1: cytotoxic necrotizing factors; fimA: encoding type 1 fimbriae; papC allele III: adhesion PapG class III; papC: P fimbriae; eae: Intimin; aer: aerobactin iron uptake system; hlyA: hemolysin. *: Virulence associated shown in boldface are the gene characteristics of E. coli pathovars.

\subsection{Serotyping and Molecular Typing of ESBL-E. coli Strains}

The analysis of MLST showed six sequence types (STs), being 6 ST131, 5 ST155, 3 ST10, 3 ST58, 2 ST2179 and 1 ST1011. Six CTX-M-15 producing E. coli type ST131-B2 belonged to the serotype $\mathrm{O} 25 \mathrm{~b}$ but none of them presented the serotype O25a or contained the new described operon afa/dra. Taken together, the combination of both typing methods showed the following classification, according to the type of produced enzyme: (i) CTXM-15-positive isolates: ST131-B2 $(n=6)$, (ii) CTX-M-1-positive isolates: ST155-D $(n=5)+$ ST10-D/A $(n=2 / 1)+$ ST58-D/A $(n=2 / 1)$, (iii) CMY-2-positive isolates: ST2179-B1 $(n=2)$ $+\mathrm{ST} 1011-\mathrm{B} 1(n=1)$.

\subsection{Phylogeny of Resistance, Virulence Genes and Clone in E. coli Strains}

Figure S1 illustrates the relationships between sample origin, resistance and virulence genes, sequence type, and pathovars of ESBL/AmpC producing E. coli isolates.

Noteworthy, all ESBL producing E. coli strains harboring the sequence type ST131CTX-M-15 clustered together and showed the same virulence determinants, pathovar, and integron 1 carried the same arrangement of gene cassettes; while only one ST131-E. coli strain did not contain integrons. In addition, all isolated ST131-E. coli did not harbor the same resistance genes detected outside integrons (Table 1, Figure S1). Conversely, the CTX-M-1 E. coli producing strains with different sequence types (ST) (ST155, ST58, ST10), different resistance, virulence genotyping, and pathovars were clustered together, except the strain EC15 that is clustered alone and affiliated to the ST155. In addition, the strains EC5 and EC9 recovered from tracheal samples lost their qnrB gene in a fecal sample collected from the same animal (EC7, EC15). 


\section{Discussion}

To the best of our knowledge, there is no published information regarding clonal lineages and virulence factors of ESBL/pAmpc producing E. coli from diarrheic chickens, in Tunisia. Only very limited data on the prevalence and molecular characterization of ESBL E. coli producing strains isolated from healthy animals, food-producing animals, and chickens suffering from colibacillosis, are available from Africa and Tunisia $[2,10]$.

For this, 130 avian samples collected from diarrheic chickens of a commercial farm, were analyzed and $20(15.4 \%)$ cefotaxime-resistant $E$. coli isolates from fecal and tracheal swabs were detected. Among them, 17 were ESBL and three pAmpC producers. These findings were similar to few published studies reporting the presence of ESBL-E. coli producing isolates in clinical chickens suffering from colibacillosis, in Tunisia, and showing much higher frequency (58.3\%) of ESBL-producers than found in our study [11]. In addition, the percentage of ESBL-E. coli isolates reported in our study (15.5\%) were higher than that found, respectively, in feces and internal organs in chickens with colibacillosis $(4.1 \%, 0 \%)[12,13]$. It is important to note that $14 \mathrm{ESBL} / \mathrm{AmpC}$-producing E. coli strains detected in this study were isolated from fecal and tracheal samples from the same chickens with diarrhea in different departments of the farm. It seems that these strains are infectious agents present in the visited farm. The spread of multi-resistance ESBL/AmpC producing E. coli strains, in livestock in Tunisia, could be related to the selection pressure that abusive antimicrobial use in animals might generate. The widespread use of different classes of antibiotics as growth factors or for therapeutic and preventive control in poultry is not very documented and remains largely unregulated in African countries [14].

In the present study, it was shown that $b a_{\mathrm{CTXM}-1}$ associated or not to $b l a_{\mathrm{TEM} 1-\mathrm{B}}$ is the most ESBL gene detected in diarrheic chickens. Indeed, in Tunisia, the $b a_{\mathrm{CTXM}}-1$ gene was frequently detected in E. coli isolates from healthy poultry and pet $[2,15]$ and accounted as one of the major ESBL genes reported in animals worldwide, especially in African livestock [2]. Surprisingly, aside from the ESBL enzyme CTX-M-1 characterized in E. coli isolates, the $b l a_{\mathrm{CTX}-\mathrm{M}-15}$ gene was detected in six isolates. CTX-M-15 has been frequently reported from human ESBL-producing Enterobacteriaceae in Africa, including Tunisia, and in other regions of the world $[2,16,17]$. In addition, it appears more prevalent in cattle than in other animal livestock [12]. CTX-M-15 was reported in bovine mastitis and feces of healthy poultry and sheep, in Tunisia $[18,19]$ and from internal organs of chickens with septicemia and colibacillosis, in Algeria [2].

In the same way, the present study constitutes the first description of $b l a_{\mathrm{CMY}-2}$-positive E. coli strains, isolated from poultry with diarrhea in Tunisia. However, this $\beta$-lactamase variant was also identified among commensally E. coli from healthy chickens, in Tunisia $[5,20]$, Algeria [21], septicemic broilers in Egypt [10], healthy humans, pets and food animals, worldwide [18,22].

Dissemination of ESBL/AmpC-encoding genes has been largely linked to the spread of some particular competitive international high-risk clones; this emergence was also observed for our studied isolates. Indeed, the international high-risk clones ST131, ST155, ST10 were found in six and three ESBL-producing isolates, respectively. The ST131 isolates were CTX-M-15 producers and were associated with the serotype O25b, and assigned to the phylogenetic group B2. To the best of our knowledge, this study is the first to reveal the presence of the pandemic high-risk human lineage CTX-M-15-B2-O25b-ST131 E. coli from diseased chickens in Tunisia. Furthermore, such isolates were the major global clone in human CTX-M-15-producing E. coli strains. They have also been identified at low frequencies in healthy swine in Tanzania [23], the blood of septicemic broilers in Egypt [10], healthy poultry and pig in Spain, as well as in companion and non-companion animals (seagulls and rates both of which have close contact with human) [19,24]. In Tunisia, many studies have reported the occurrence of ST131 in human settings (hospitalized patients with urinary infection, newborns, patients in intensive care units, clinical samples [6,25-27]. The wide spread of the ST131 clone is mainly linked to competitiveness and armament by genes encoding antibiotic resistance and virulence factors. In addition, all these isolates 
harbored the same profile of virulence genes (cnf1-fimA-papG-aer-papC) and were assigned as ExPEC. They were quinolone-resistant and trimethoprim/sulfamethoxazole resistant coded, respectively, by variant $a a c\left(6^{\prime}\right)-I b-c r$ and integrons class 1 . These results are similar to others reporting worldwide that fluoroquinolone and trimethoprim/sulfamethoxazole resistance are significant markers of ST131 clone and the "dual substrate" aminoglycosidemodifying enzyme $a a c\left(6^{\prime}\right)$-ib-cr contributes to quinolone resistance via acetylation [24].

The presence of the clone ST155 (five isolates) and ST10 (3 isolates) harboring the $b l a_{\text {CTXM-1 }}$ gene was similar to other studies reporting that these lineages are associated with multi-drug resistance, mainly CTX-M variants [28]. It is worthy to note that ST155 has commonly been reported in healthy poultry in Tunisia and Africa [2,6,28]. It appears to be associated with a zoonotic risk, suggested by some studies [28]. In addition, the ST10 was highly distributed among various animal livestock and humans in Africa [2]. In Tunisia, it was also reported in E. coli from food origins [29] and recently considered as the most disseminated among commensal E. coli, worldwide [30]. The ST10 and ST155 clones were detected in Algerian farmlands and associated with colistin resistance [31]. These findings of sequence type ST2179 and ST1011 related to CMY-2, in our collection, were also reported from healthy chickens in Tunisia and Algeria [2,20].

The ISEcp 1 insertion sequence has been identified upstream $b l a_{\mathrm{CTX}-\mathrm{M}}$ and $b l a_{\mathrm{CMY}-2}$ genes and, interestingly, in three isolates, IS26 flanked a partially truncated ISEcp 1 element. These results suggested a crucial role of ISEcp1-like sequences in the mobilization and expression of $b l a_{\text {CTX-M }}$ genes $[1,7]$.

The detection of class 1 integron in eleven CTX-M positive E. coli, with a different arrangement of gene cassettes $d f r$ and aad, conferred trimethoprim and streptomycin resistance, respectively. This finding agreed with many studies from different origins in Tunisia and Africa [2,32].

Furthermore, the observed quinolone resistance encoded by qnrB plasmid could be due to the overuse of this antibiotic family in chickens to treat or prevent bacterial infections in poultry farms. This result was similar to previous studies interested in livestock infections [33]. The presence of qnrB plasmid in E. coli strains isolated from tracheal samples and not recovered from fecal samples of the same animal, showed that these strains could lose this plasmid during their passage through the digestive tract.

The presence of ESBL/AmpC E. coli producing strains harbored CTX-M-1 in the same cluster and assigned to different clonal lineages (ST155, ST58, ST10) could be due to the horizontal transmission of plasmids bearing these ESBL genes. In this sense, a few molecular studies in Tunisia described that CTXM-1 was broadly disseminated in healthy poultry associated with Inc1/ST3 plasmids [12,34]. Nevertheless, the phylogenetic presence of ESBL producing E. coli strain EC15/ST155 harbored CTX-M-1 in distant clusters suggested that the ESBL gene was carried by another type of plasmid. The detection of ESBL E. coli ST131-CTX-M-15-B2 classified in the same cluster could be due to its association with the same replicon plasmid. This finding agreed with studies in Africa [2].

Phylogenetic analyses have shown that the majority of ours strains are assigned to the phylogroups B2 and D with three to five virulence factors; only three strains being affiliated to the phylogroup B1. These findings were in concordance with those of other studies that report pathogenic strains producing enteropathogenic (EPEC) and extraintestinal (ExPEC) infections mainly belonging to the phylogroups $\mathrm{B} 2$ and $\mathrm{D}$ [35].

According to the content of genes encoding virulence factors, six isolates were classified as atypical EPEC owing to the presence of intimin and the absence of bundle forming pili encoding eae and $b f p$ genes, respectively. The results corroborated with other studies describing animals, especially poultry, as the major reservoir of EPEC, which constitutes the major zoonotic enteropathogenic bacteria $[4,36]$. Furthermore, the remaining E. coli isolates were assigned to the ExPEC group with the presence of virulence genes specific to this pathovar [32]. ExPEC is widespread amongst animal reservoirs and causes several infections [3,37]. Besides, our strain collection harbored the cytotoxic necrotizing factor (cnf1) and type 1 fimbria (fimA); these virulence factors are reported as the most important 
virulence factor genes found in E. coli strains with P fimbria (pap), fimbrial adhesion I (afa) and aerobactin (aer) [38]>.

\section{Materials and Methods}

\subsection{Sampling}

Eighty fecal and 50 tracheal samples were collected from commercial chickens with diarrhea, reared in a farm in the region of Sidi Thabet (North of Tunisia), in 2015. The farm contained 13 broiler houses, each accommodating 10,000 birds and from which cloacal and tracheal swabs were taken by the veterinarian. All samples, collected from diseased animals that show clinical symptoms such as dyspnea, reduced appetite, and diarrhea, were directly transferred under cold conditions to the laboratory and immediately processed. Table 1 presents the details of sampling.

\subsection{Isolation and Identification}

The swabs were suspended in $5 \mathrm{~mL}$ of brain-heart broth (Biolife, Italy) and incubated for $24 \mathrm{~h}$ at $37^{\circ} \mathrm{C}$. After serial dilutions, $100 \mu \mathrm{L}$ of the bacterial suspension were streaked onto MacConkey (Biolife, Italy) agar plates supplemented with cefotaxime $(2 \mu \mathrm{g} / \mathrm{mL})$ and imipenem $(1 \mu \mathrm{g} / \mathrm{mL})$. Colonies with typical E. coli morphology were selected (one colony per sample) and identified by classical biochemical methods for catalase, oxidase, indole, citrate, and urease characters. The E. coli isolates were submitted to molecular identification by species-specific PCR of the uidA gene [39]; E. coli strain ATCC 25922 was used as a control.

\subsection{Antimicrobial Susceptibility Testing}

Antimicrobial susceptibility testing was conducted on Mueller-Hinton agar (Biolife, Milano, Italy) plates using the agar disk diffusion method, according to Clinical and Laboratory Standards Institute (CLSI) criteria [40]. The tested antibiotics were ( $\mu \mathrm{g} / \mathrm{disc})$ : ampicillin (10), ticarcillin (75), amoxicillin/clavulanic acid $(20+10)$, cefoxitin (30), ceftazidime (30), cefotaxime (30), Imipenem (10), ertapenem (10), gentamicin (10), tobramycin (10), streptomycin (10), nalidixic acid (30), ciprofloxacin (5), sulphonamides (200), trimethoprim/sulfamethoxazole $(1.25+23.75)$, tetracycline (30), and chloramphenicol (30). E. coli strain ATCC 25922 was used as a control strain. A screening test for the detection of ESBLs was carried out by the (DDST), according to the CLSI criteria [40] and using previously reported strain collection [39].

\subsection{Characterization of Beta-Lactamase Genes and Genetic Environment of bla $a_{C T X-M}$ Genes}

The genes encoding TEM, SHV, OXA-1, CTX-M, CMY type beta-lactamases in all ESBLpositive isolates were analyzed by specific PCRs, as previously reported [39]. All obtained amplicons were sequenced on both strands and sequences were compared with those included in the GenBank database and the Lahey clinical website (http:/ / www.Lahey.org/ Studies / webt.html, accessed on 17 June 2019), to identify the specific type of beta-lactamase gene [41]. The ISEcp1, IS26, and orf477 sequences surrounding the $b l a_{\mathrm{CTX}-\mathrm{M}}$ and $b l a_{\mathrm{CMY}}$ genes were analyzed by PCR, using previously described primers and conditions [16]. All obtained amplicons were sequenced for confirmation. Positive and negative control strains, from the collection of the Laboratory of Epidemiology and Veterinary Microbiology, at Institute Pasteur of Tunis, were included in all the PCR assays [16,39].

\subsection{Characterization of Integrons and Resistance Mechanisms to Non- $\beta$-Lactam Antimicrobial Agents}

The presence of genes associated with the resistance to tetracycline (tet $A$ and $\operatorname{tet} B)$, sulphonamides (sul1, sul2, and sul3), streptomycin (strA and strB), and quinolone (qnrA, $q n r B$, qnrS and $\left.a a c\left(6^{\prime}\right)-I b-c r\right)$, was determined for all resistant $E$. coli isolates by PCR [42]. The $a a c\left(6^{\prime}\right)-I b$ amplicons were sequenced to identify aac $\left(6^{\prime}\right)$-Ib-cr variant. 
The presence of intI 1 and int 2 genes encoding class 1 and class 2 integrases, respectively, and the $3^{\prime}$-conserved segment ( $\left.3^{\prime}-\mathrm{CS}\right)$ ( $q a c \mathrm{E} \Delta 1$-sul1 genes) of class 1 integrons were examined by PCR [42]. Variable regions of class 1 integrons were characterized by PCR and DNA of all int11-positive isolates sequenced [42].

\subsection{Serotyping and Virulence Genotyping of E. coli}

The E. coli isolates were screened by single or multiplex PCR assays for the presence of the eight genes encoding the following virulence factors: fim $A$ (type 1 fimbriae), pap $G$ allele III (adhesin PapG class III), hlyA (hemolysin), cnf1 (cytotoxic necrotizing factor), papC (P fimbriae), aer (aerobactin iron uptake system) [encoding virulence factors often found in ExPEC isolates], eae (Intimin) and bfp (Type IV bundle forming pili) genes [encoding virulence factors often found in EPEC isolates] [43]. EPEC strains possess specific virulence factors such as intimin adhesin (encoded by the eae gene) and can be classified as typical or atypical EPEC based on the presence or the absence of bundle-forming pili (encoded by the $b f p$ operon) [4]. All isolates were screened for O25a and O25b serotypes [35,44], as well as the new diffuse adhesion encoding afa operon (Gen Bank accession number FM955495), specific for O25b:H4 ST131 producing CTXM-15 isolates [44].

\subsection{Molecular Typing of ESBL-E. coli Isolates}

The E. coli isolates were characterized by Multilocus-Sequence Typing (MLST) using PCR amplification of the standard seven housekeeping loci [45]. All the amplicons were sequenced and compared with the sequences deposited in the MLST database to know the specific allele combination and the sequence type (ST). In addition, identification of the major phylogenetic groups' A, B1, B2, or D of E. coli isolates was determined by PCR using a combination of three genes (chuA, yjaA, and TspE4.C2), as previously described [46].

\subsection{Data Analysis}

The sequence of extended-spectrum $\beta$ - lactamase genes and the seven housekeeping genes for each strain were aligned using Muscle (doi:10.1093/nar/gkh340) and Phyml (doi:10.1093/nar/gki352) (1000 bootstrap iterations) software's to respectively generate the alignment and infer the maximum likelihood-based phylogeny. A model testing was undertaken to assess the use of the GTR model with SMS (https:/ / doi.org/10.1093/ molbev / msx149, accessed on 9 September 2017).

The gene presence/absence regarding the antibioresistance and the virulence factors, the phylogroup name, the sequence type, and the pathovar classification were mapped to the phylogenetic tree and visualized with Phandango webtool (doi:10.1093/bioinformatics/ btx610).

\section{Conclusions}

Diseased chickens have become an important reservoir of cefotaxime-resistant $E$. coli clones, exhibiting multi-drug phenotypes and harboring various virulence determinants. Our study highlighted the presence of the human high-risk clonal lineages CTX-M-15B2-O25-ST131 E. coli, ST10, ST155, and ST58. Despite the low number of studied isolates, ESBL- and AmpC-producing isolates belong to six clones highlighting the general concept of particular clone spread within the considered farm and the risk of circulation of such clones associated with integrons, qnr plasmid, and CTXM/CMY genes in healthy animals and humans. In addition, these multi-drug E. coli clones were associated with pathogenic pathovars which warrant possible human infections by such strains via direct contact with poultry feces or via the food chain. Hence, increased efforts of antibiotic surveillance to control and regulate the use of antimicrobial agents in poultry farms, in Tunisia, are required to reduce the risk factors associated with the acquisition of multi-resistant clones harboring virulence determinant, allowing prevention and control of the spread of pathogenic bacteria into the environment and to humans. 
Supplementary Materials: The following are available online at https:/ / www.mdpi.com/article/10 .3390 / antibiotics10060670/s1, Figure S1: Clustering analysis of genetic variation and clonal diversity of $20 \mathrm{ESBL} / \mathrm{AmpC}$ producing E. coli isolates recovered from fecal and tracheal samples of diarrheic chicken farm in Tunisia. Chicken ID: chicken identified.

Author Contributions: Conceptualization, A.J.; Data curation, A.J.; Methodology A.J. and A.M.; investigation, A.J., A.K. and M.B.C.; supervision, A.J. and A.M.; validation, A.J., A.K. and A.M.; formal analysis, O.S. and M.H.; resources, I.E. and S.H.; visualization, A.J.; writing—original draft, A.J.; writing-review, A.J.; Writing-review and editing English, A.J., A.M. and A.G.; funding acquisition, A.M.; Project administration, A.J. and A.M. All authors have read and agreed to the published version of the manuscript.

Funding: This work was supported by the Tunisian Ministry of Higher Education, Scientific Research, and Technology (LR11IPT03).

Institutional Review Board Statement: The study underwent ethical review and was approved by the Bio-Medical Ethics Animal Committee at Institute Pasteur of Tunis.

Data Availability Statement: All supporting data, code and protocols have been provided within the article or through supplementary data files. One Supplementary Figure S1 is available with the online version of this article.

Conflicts of Interest: No competing financial interest exists.

\section{References}

1. Poirel, L.; Madec, J.-Y.; Lupo, A.; Schink, A.-K.; Kieffer, N.; Nordmann, P.; Schwarz, S. Antimicrobial Resistance in Escherichia coli. In Antimicrobial Resistance in Bacteria from Livestock and Companion Animals; ASM Press: Washington, DC, USA, 2018 ; pp. $289-316$. [CrossRef]

2. Alonso, C.A.; Zarazaga, M.; Ben Sallem, R.; Jouini, A.; Ben Slama, K.; Torres, C. Antibiotic resistance in Escherichia coli in husbandry animals: The African perspective. Lett. Appl. Microbiol. 2017, 64, 318-334. [CrossRef] [PubMed]

3. Sarowska, J.; Futoma-Koloch, B.; Jama-Kmiecik, A.; Frej-Madrzak, M.; Ksiazczyk, M.; Bugla-Ploskonska, G.; Choroszy-Krol, I. Virulence factors, prevalence and potential transmission of extraintestinal pathogenic Escherichia coli isolated from different sources: Recent reports. Gut Pathog. 2019, 11, 10. [CrossRef] [PubMed]

4. Tanabe, R.H.S.; Vieira, M.A.; Mariano, N.A.B.; Dias, R.C.B.; Da Silva, R.V.; Castro, C.M.; Dos Santos, L.F.; Camargo, C.H.; Yamatogi, R.S.; Rall, V.L.M.; et al. Identification and characterization of atypical enteropathogenic and Shiga toxin-producing Escherichia coli isolated from ground beef and poultry breast purchased in Botucatu, Brazil. Braz. J. Microbiol. 2019, 50, 1099-1103. [CrossRef]

5. Ben Sallem, R.; Ben Slama, K.; Sáenz, Y.; Rojo-Bezares, B.; Estepa, V.; Jouini, A.; Gharsa, H.; Klibi, N.; Boudabous, A.; Torres, C. Prevalence and Characterization of Extended-Spectrum Beta-Lactamase (ESBL)- and CMY-2-Producing Escherichia coli Isolates from Healthy Food-Producing Animals in Tunisia. Foodborne Pathog. Dis. 2012, 9, 1137-1142. [CrossRef] [PubMed]

6. Maamar, E.; Ferjani, S.; Jendoubi, A.; Hammami, S.; Hamzaoui, Z.; Mayonnove-Coulange, L.; Saidani, M.; Kammoun, A.; Rehaiem, A.; Ghedira, S.; et al. High Prevalence of Gut Microbiota Colonization with Broad-Spectrum Cephalosporin Resistant Enterobacteriaceae in a Tunisian Intensive Care Unit. Front. Microbiol. 2016, 7, 1859. [CrossRef]

7. Bevan, E.R.; Jones, A.M.; Hawkey, P.M. Global epidemiology of CTX-M $\beta$-lactamases: Temporal and geographical shifts in genotype. J. Antimicrob. Chemother. 2017, 72, 2145-2155. [CrossRef]

8. Liu, C.M.; Stegger, M.; Aziz, M.; Johnson, T.J.; Waits, K.; Nordstrom, L.; Gauld, L.; Weaver, B.; Rolland, D.; Statham, S.; et al. Escherichia coli ST131-H22 as a Foodborne Uropathogen. mBio 2018, 9, e00470-18. [CrossRef]

9. Qureshi, Z.; Doi, Y. Escherichia coli sequence type 131: Epidemiology and challenges in treatment. Expert Rev. Anti-Infective Ther. 2014, 12, 597-609. [CrossRef]

10. Ahmed, A.M.; Shimamoto, T.; Shimamoto, T. Molecular characterization of multidrug-resistant avian pathogenic Escherichia coli isolated from septicemic broilers. Int. J. Med. Microbiol. 2013, 303, 475-483. [CrossRef] [PubMed]

11. Dhaouadi, S.; Soufi, L.; Hamza, A.; Fedida, D.; Zied, C.; Awadhi, E.; Mtibaa, M.; Hassen, B.; Cherif, A.; Torres, C.; et al. Cooccurrence of mcr-1 mediated colistin resistance and $\beta$-lactamase-encoding genes in multidrug-resistant Escherichia coli from broiler chickens with colibacillosis in Tunisia. J. Glob. Antimicrob. Resist. 2020, 22, 538-545. [CrossRef]

12. Grami, R.; Mansour, W.; Dahmen, S.; Mehri, W.; Haenni, M.; Aouni, M.; Madec, J.-Y. The blaCTX-M-1 IncI1/ST3 plasmid is dominant in chickens and pets in Tunisia. J. Antimicrob. Chemother. 2013, 68, 2950-2952. [CrossRef]

13. Grami, R.; Dahmen, S.; Mansour, W.; Mehri, W.; Haenni, M.; Aouni, M.; Madec, J.-Y. blaCTX-M-15-Carrying F2:A-:B- Plasmid in Escherichia coli from Cattle Milk in Tunisia. Microb. Drug Resist. 2014, 20, 344-349. [CrossRef]

14. Maron, D.F.; Smith, T.J.S.; Nachman, K. Restrictions on antimicrobial use in food animal production: An international regulatory and economic survey. Glob. Health 2013, 9, 48. [CrossRef] [PubMed] 
15. Ben Sallem, R.; Gharsa, H.; Ben Slama, K.; Rojo-Bezares, B.; Estepa, V.; Porres-Osante, N.; Jouini, A.; Klibi, N.; Sáenz, Y.; Boudabous, A.; et al. First Detection of CTX-M-1, CMY-2, and QnrB19 Resistance Mechanisms in Fecal Escherichia coli Isolates from Healthy Pets in Tunisia. Vector-Borne Zoonotic Dis. 2013, 13, 98-102. [CrossRef]

16. Jouini, A.; Ben Slama, K.; Vinué, L.; Ruiz, E.; Sáenz, Y.; Somalo, S.; Klibi, N.; Zarazaga, M.; Ben Moussa, M.; Boudabous, A.; et al. Detection of Unrelated Escherichia coli Strains Harboring Genes of CTX-M-15, OXA-1, and AAC(6')-Ib-Cr Enzymes in a Tunisian Hospital and Characterization of Their Integrons and Virulence Factors. J. Chemother. 2010, 22, 318-323. [CrossRef] [PubMed]

17. Storberg, V. ESBL-producingEnterobacteriaceaein Africa-A non-systematic literature review of research published $2008-2012$. Infect. Ecol. Epidemiol. 2014, 4, 20342. [CrossRef] [PubMed]

18. Saidani, M.; Messadi, L.; Soudani, A.; Daaloul-Jedidi, M.; Châtre, P.; Ben Chehida, F.; Mamlouk, A.; Mahjoub, W.; Madec, J.-Y.; Haenni, M. Epidemiology, Antimicrobial Resistance, and Extended-Spectrum Beta-Lactamase-Producing Enterobacteriaceae in Clinical Bovine Mastitis in Tunisia. Microb. Drug Resist. 2018, 24, 1242-1248. [CrossRef]

19. Sghaier, S.; Abbassi, M.S.; Pascual, A.; Serrano, L.; De-Alba, P.D.-; Ben Said, M.; Hassen, B.; Ibrahim, C.; Hassen, A.; López-Cerero, L. Extended-spectrum $\beta$-lactamase-producing Enterobacteriaceae from animal origin and wastewater in Tunisia: First detection of O25b-B23-CTX-M-27-ST131 Escherichia coli and CTX-M-15/OXA-204-producing Citrobacter freundii from wastewater. J. Glob. Antimicrob. Resist. 2019, 17, 189-194. [CrossRef]

20. Maamar, E.; Alonso, C.A.; Hamzaoui, Z.; Dakhli, N.; Abbassi, M.S.; Ferjani, S.; Saidani, M.; Boubaker, I.B.-B.; Torres, C. Emergence of plasmid-mediated colistin-resistance in CMY-2-producing Escherichia coli of lineage ST2197 in a Tunisian poultry farm. Int. J. Food Microbiol. 2018, 269, 60-63. [CrossRef]

21. Meguenni, N.; Le Devendec, L.; Jouy, E.; Le Corvec, M.; Bounar-Kechih, S.; Bakour, R.; Kempf, I. First Description of an Extended-Spectrum Cephalosporin- and Fluoroquinolone-Resistant Avian Pathogenic Escherichia coli Clone in Algeria. Avian Dis. 2015, 59, 20-23. [CrossRef]

22. Madec, J.-Y.; Haenni, M.; Nordmann, P.; Poirel, L. Extended-spectrum $\beta$-lactamase/AmpC- and carbapenemase-producing Enterobacteriaceae in animals: A threat for humans? Clin. Microbiol. Infect. 2017, 23, 826-833. [CrossRef]

23. Seni, J.; Falgenhauer, L.; Simeo, N.; Mirambo, M.M.; Imirzalioglu, C.; Matee, M.; Rweyemamu, M.; Chakraborty, T.; Mshana, S.E. Multiple ESBL-producing Escherichia coli sequence types carrying quino-lone and aminoglycoside resistance genes circulating in companion and domestic farm animals in Mwanza, Tanzania, harbor commonly occurring plasmids. Front. Microbiol. 2016, 7, 142. [CrossRef] [PubMed]

24. Rogers, B.A.; Sidjabat, H.E.; Paterson, D.L. Escherichia coli O25b-ST131: A pandemic, multiresistant, community-associated strain. J. Antimicrob. Chemother. 2010, 66, 1-14. [CrossRef]

25. Lahlaoui, H.; Ben Moussa, M. CTX-M-14 type $\beta$-Lactamase producing Escherichia coli isolated from hospitalized patients in Tunisia. APMIS 2011, 119, 759-761. [CrossRef] [PubMed]

26. Lahlaoui, H.; De Luca, F.; Maradel, S.; Ben-Haj-Khalifa, A.; Ben Hamouda, H.; Kheder, M.; Ben Moussa, M.; Rossillini, G.-M.; Docquier, J.-D. Occurrence of conjugative IncF-type plasmids harboring the blaCTX-M-15 gene in Enterobacteriaceae isolates from newborns in Tunisia. Pediatr. Res. 2014, 77, 107-110. [CrossRef]

27. Dziri, O.; Dziri, R.; Maraoub, A.; Chouchani, C. Characterization of O25b-ST131 Escherichia coli Clone Producing CTX-M-15, DHA-4, and CMY-42 in Urinary Tract Infections in a Tunisian Island. Microb. Drug Resist. 2020, 26, 741-746. [CrossRef]

28. Dandachi, I.; Sokhn, E.S.; Dahdouh, E.A.; Azar, E.; El-Bazzal, B.; Rolain, J.-M.; Daoud, Z. Prevalence and Characterization of Multi-Drug-Resistant Gram-Negative Bacilli Isolated from Lebanese Poultry: A Nationwide Study. Front. Microbiol. 2018, 9, 550. [CrossRef]

29. Jouini, A.; Ben Slama, K.; Klibi, N.; Ben Sallem, R.; Estepa, V.; Vinué, L.; Sáenz, Y.; Ruiz-Larrea, F.; Boudabous, A.; Torres, C. Lineages and Virulence Gene Content among Extended-Spectrum $\beta$-Lactamase-Producing Escherichia coli Strains of Food Origin in Tunisia. J. Food Prot. 2013, 76, 323-327. [CrossRef] [PubMed]

30. Reid, C.J.; DeMaere, M.Z.; Djordjevic, S.P. Australian porcine clonal complex 10 (CC10) Escherichia coli belong to multiple sublineages of a highly diverse global CC10 phylogeny. Microb. Genom. 2019, 5, 3. [CrossRef]

31. Touati, M.; Hadjadj, L.; Berrazeg, M.; Baron, S.A.; Rolain, J.M. Emergence of Escherichia coli harbouring mcr-1 and mcr-3 genes in North West Algerian farmlands. J. Glob. Antimicrob. Resist. 2020, 21, 132-137. [CrossRef]

32. Kilani, H.; Ferjani, S.; Mansouri, R.; Boutiba-Benboubaker, I.; Abbassi, M.S. Occurrence of plasmid-mediated quinolone resistance determinants among Escherichia coli strains isolated from animals in Tunisia: Specific pathovars acquired qnr genes. J. Glob. Antimicrob. Resist. 2020, 20, 50-55. [CrossRef]

33. Yanat, B.; Rodríguez-Martínez, J.-M.; Touati, A. Plasmid-mediated quinolone resistance in Enterobacteriaceae: A systematic review with a focus on Mediterranean countries. Eur. J. Clin. Microbiol. Infect. Dis. 2016, 36, 421-435. [CrossRef]

34. Ben Sallem, R.; Ben Slama, K.; Rojo-Bezares, B.; Porres-Osante, N.; Jouini, A.; Klibi, N.; Boudabous, A.; Sáenz, Y.; Torres, C. IncI1 Plasmids Carrying blaCTX-M-1 or blaCMY-2 Genes in Escherichia coli from Healthy Humans and Animals in Tunisia. Microb. Drug Resist. 2014, 20, 495-500. [CrossRef]

35. Clermont, O.; Lavollay, M.; Vimont, S.; Deschamps, C.; Forestier, C.; Branger, C.; Denamur, E.; Arlet, G. The CTX-M-15-producing Escherichia coli diffusing clone belongs to a highly virulent B2 phylogenetic subgroup. J. Antimicrob. Chemother. 2008, 61, $1024-1028$. [CrossRef]

36. Doregiraee, F.; Alebouyeh, M.; Fasaei, B.N.; Charkhkar, S.; Tajedin, E.; Zali, M.R. Isolation of atypical enteropathogenic and shiga toxin encoding Escherichia coli strains from poultry in Tehran, Iran. Gastroenterol. Hepatol. Bed Bench 2016, 9, 53-57. [PubMed] 
37. Bélanger, L.; Garenaux, A.; Harel, J.; Boulianne, M.; Nadeau, E.; Dozois, C.M. Escherichia coli from animal reservoirs as a potential source of human extraintestinal pathogenic E. coli. FEMS Immunol. Med. Microbiol. 2011, 62, 1-10. [CrossRef]

38. Momtaz, H.; Karimian, A.; Madani, M.; Dehkordi, F.S.; Ranjbar, R.; Sarshar, M.; Souod, N. Uropathogenic Escherichia coli in Iran: Serogroup distributions, virulence factors and antimicrobial resistance properties. Ann. Clin. Microbiol. Antimicrob. $2013,12,8$. [CrossRef] [PubMed]

39. Jouini, A.; Vinué, L.; Ben Slama, K.; Sáenz, Y.; Klibi, N.; Hammami, S.; Boudabous, A.; Torres, C. Characterization of CTX-M and SHV extended-spectrum -lactamases and associated resistance genes in Escherichia coli strains of food samples in Tunisia. J. Antimicrob. Chemother. 2007, 60, 1137-1141. [CrossRef]

40. CLSI. Susceptibility Testing Twenty-Fourth. International Supplement. CLSI Document M100-S24, 34,1; Clinical Laboratory Standard Institute: Wayne, PA, USA, 2013.

41. Studies Pages, Lahey Health. Available online: http:/ / www.lahey.org/Studies/webt.html (accessed on 17 June 2019 ).

42. Sáenz, Y.; Briñas, L.; Domínguez, E.; Ruiz, J.; Zarazaga, M.; Vila, J.; Torres, C.; Petraitis, V.; Petraitiene, R.; Kelaher, A.M.; et al. Mechanisms of Resistance in Multiple-Antibiotic-Resistant Escherichia coli Strains of Human, Animal, and Food Origins. Antimicrob. Agents Chemother. 2004, 48, 3959-3967. [CrossRef]

43. Ruiz, J.; Simon, K.; Horcajada, J.P.; Velasco, M.; Barranco, M.; Roig, G.; Moreno-Martínez, A.; Martínez, J.A.; De Anta, T.J.; Mensa, J.; et al. Differences in Virulence Factors among Clinical Isolates of Escherichia coli Causing Cystitis and Pyelonephritis in Women and Prostatitis in Men. J. Clin. Microbiol. 2002, 40, 4445-4449. [CrossRef] [PubMed]

44. Blanco, M.; Alonso, M.P.; Nicolas-Chanoine, M.-H.; Dahbi, G.; Mora, A.; Blanco, J.E.; López, C.; Cortés, P.; Llagostera, M.; Leflon-Guibout, V.; et al. Molecular epidemiology of Escherichia coli producing extended-spectrum $\beta$-lactamases in Lugo (Spain): Dissemination of clone O25b:H4-ST131 producing CTX-M-15. J. Antimicrob. Chemother. 2009, 63, 1135-1141. [CrossRef] [PubMed]

45. Tartof, S.Y.; Solberg, O.D.; Manges, A.R.; Riley, L.W. Analysis of a Uropathogenic Escherichia coli Clonal Group by Multilocus Sequence Typing. J. Clin. Microbiol. 2005, 43, 5860-5864. [CrossRef] [PubMed]

46. Clermont, O.; Bonacorsi, S.; Bingen, E. Rapid and Simple Determination of the Escherichia coli Phylogenetic Group. Appl. Environ. Microbiol. 2000, 66, 4555-4558. [CrossRef] [PubMed] 